\title{
The Peaceful Conspiracy: Bond Markets and International Relations During the Pax Britannica
}

\author{
Marc Flandreau and Juan H. Flores
}

\begin{abstract}
This article provides foundations to Polanyi's famed argument that monopoly power in the global capital market served as an instrument of peace during the Pax Britannica (1815-1914). Our perspective is novel-we focus on the role of intermediaries and certification. We show that when information and enforcement are imperfect, there is scope for the endogenous emergence of "prestigious" intermediaries who enjoy a monopoly position and as a result, control government actions. They can implement conditional lending: they subject the distribution of credit to the adoption of peaceful policies. Prestigious intermediaries act that way because of their concern with maintaining an unblemished track record when wars increased risks of default. Our analysis, which brings together insights from different disciplines, provides a significant extension to, and departure from, recent research on how countries accumulate reputational capital.
\end{abstract}

In the pantheon of international political economy (IPE), Karl Polanyi's Great Transformation occupies a central position. His famed conjecture that financiers were responsible for the "Hundred Years Peace" between the Congress of Vienna (1815) and the Austrian Archduke Franz-Ferdinand's assassination in Sarajevo (1914) provides an early recognition of the interrelations between economics and politics. Polanyi claimed that peace was the result of conscious actions by a subgroup of financiers, which he called "Haute Finance" and within which the House of Rothschild reigned supreme, "embodying the principle of abstract internationalism" (whatever is meant by that beautiful phrase). As he argued:

The authors are grateful to Melanie Aspey from the Rothschild Archive, London, for her support and access to the Rothschild Frères Archive in the Centre d'Archives du Monde du Travail, Roubaix, France. We thank Jim Alt, Chris Ansell, Gopalan Balachandran, Thomas Biersteker, Jerry Cohen, Jeff Frieden, Deirdre McCloskey, Ken Shepsle, and Stefano Ugolini for advice and suggestions. This article also received extensive criticism from the editors of International Organization and three anonymous referees whose comments proved extremely helpful. Errors and misinterpretation are ours. Last, we warmly thank Jacqueline Larson for kind help and many useful suggestions for stylistic improvements. We also gratefully acknowledge generous funding from Yves Mirabaud. The views expressed do not implicate him, however, nor the Banque Mirabaud et Cie.

International Organization 66, Spring 2012, pp. 211-41

(C) 2012 by The IO Foundation.

doi:10.1017/S0020818312000070 
The nineteenth century produced a phenomenon unheard of in the annals of Western civilization, namely a hundred years' peace-1815-1914. Apart from the Crimean War-a more or less colonial event-England, France, Prussia, Austria and Italy were engaged in war among each other for altogether only eighteen months.... This triumph of a pragmatic pacifism was certainly not the result of an absence of grave causes for conflict ... The entirely new factor, we submit, was the emergence of an acute peace interest. Traditionally, such an interest was regarded as outside the scope of the state system.... For an explanation of this amazing feat, we must seek for some undisclosed powerful social instrumentality at work in the new setting, which could play the role of dynasties and episcopacies under the old and make the peace interest effective. This anonymous factor was Haute Finance. ${ }^{1}$

In Polanyi's account, Haute Finance's desire and ability to use market power to influence policies toward peace did the trick: Haute Finance secured peace through a mechanism that anticipated what is known today as "political conditionality." But Polanyi's bottom line was postulated rather than demonstrated: he provided neither empirical nor theoretical foundations to explain how Haute Finance became the "anonymous factor" of a successful attempt at preventing wars. Nor did he document the actual success or track record. He recognized that "no all-around inquiry of the nature of international banking in the nineteenth century has yet been undertaken" and directed readers to the work of historians Corti, Jenks, and Feis, from which he said he had gleaned insights-although the first book is a largely hagiographic account of the House of Rothschild, and the last two quite a distance from Polanyi's theme. ${ }^{2}$ The precise reason why Haute Finance could be enlisted in the interest of peace remains obscure except when Polanyi features as a functionalist, briefly alluding to the notion that providing peace (an international public good) would have legitimized the power of Haute Finance. ${ }^{3}$

Do we know that the marketplace discriminated against wars during the nineteenth century? Could it actually lead governments to be discouraged from military undertakings? Why should financiers want peace? Tilly has argued that, in early modern Europe, states made war and wars made states and financiers benefited. ${ }^{4}$ Historians have shown that Ouvrard (Napoleon's financier) and Bleichröder (Bismarck's) enriched themselves from funding conflicts. ${ }^{5}$ Polanyi certainly did

1. Polanyi $1944,5,7,9$.

2. Compare Jenks 1927; Corti 1928; and Feis 1930 with Polanyi 1944, 9-10.

3. "Haute Finance was not designed as an instrument of peace; this function fell to it by accident.... [Haute Finance] was able to serve a new interest, which had no specific organ of its own; for the service of which no other institution happened to be available, and which was nevertheless of vital importance to the community: namely, peace." Polanyi 1944, 11-12. A bridge may be built between this perspective and Cashore 2002, who studies (in a different context) the emergence of nonstate market-driven governance systems and the conditions under which they gain authority to create policy. The perspective we articulate here is distinct, though not necessarily exclusive.

4. Tilly 1992.

5. On Ouvrard, see Wolff 1992; on Bismarck, see Stern 1977. 
not argue that an amorphous financial interest acted in an uncoordinated way to discourage war. Rather, he emphasized that a highly cohesive grouping, whose epicenter he identifies with the House of Rothschild, was in charge of implementing political conditionality. But is such a description adequate? Was Haute Finance actually behaving in a cartel-like manner, and why? We provide new data and new theoretical foundations to Polanyi's conjecture, and thereby also provide some important qualifications and insights into the relation between financial market power and international relations.

It is a widespread notion that financiers have "dictatorial" powers. Think for instance of Friedman's claim that there are two superpowers: "the United States and Moody's Investors Services." "This view has deep historical roots. When Polanyi wrote his book, he could rely on a long tradition that emphasized the existence of a "capital market conspiracy." The late nineteenth century saw the rise of a literature that personified (and vilified) the capital market. An overarching theme was that global finance acted as a cartel and reference to the Rothschilds' centrality in the "plot" abound. ${ }^{7}$ Denouncing the existence of "money trusts" became popular. ${ }^{8}$ Such accounts, generally associated with Hobson's 1902 theory of imperialism, ${ }^{9}$ eventually found their way into the works of Marxist students, such as Rudolf Hilferding and Vladimir Lenin. They argued that, given the power of Haute Finance, the occurrence of World War I was proof that Finance had wanted war (in a sin of omission, it did not work to prevent war). ${ }^{10}$ The notion and language of bankers' influence was resurrected by post-World War I historians and then back into Polanyi-although unlike the case for Hobson and his followers, the Rothschilds were now praised as friends of peace. ${ }^{11}$ With the revival of global markets and market management of reputation, this tradition is currently making a comeback. Modern IPE scholars working on investment banks, sovereign funds, or rat-

6. Interview with Thomas L. Friedman, broadcast on "The News Hour with Jim Lehrer," PBS Television, 13 February 1996. Transcript available at〈http://www.pbs.org/newshour/gergen/ friedman.html $\rangle$. Accessed 2 November 2011.

7. According to Jenks, Walther Lotz was among the first to describe the bond market as "monopolescent." See Lotz 1890; and Jenks 1927.

8. In 1908, "Lysis" achieved worldwide celebrity by publishing a blockbuster pamphlet (Against Financial Oligarchy) in which he charged that international banks were a cartelized oligarchy that held borrowing governments hostage in "game preserves" that were "jealously defended": "Trespassers are asked to walk away. One cannot do business with a foreign government without asking the authorization of the landlord." Lysis 1908, 105. On Lysis, see Beale 1999; and Berger 2003. Justice Louis Brandeis uses similar language as Lysis to depict the operation of the "Money Trust" in the United States. Brandeis 1913, chap. 1.

9. John Hobson's theory of imperialism contains one of the most famous and explicit statements to this effect, suggesting that the House of Rothschild had the power to stand in the way of wars and was therefore guilty of the sin of omission for all the conflicts that nonetheless occurred. In Hobson's words: "Does anyone seriously suppose that a great war could be undertaken by any European State, or a great State loan subscribed, if the house of Rothschild and its connections set their face against it?" Hobson's suspicion of a bankers' conspiracy also reflected his professed anti-Semitism. Hobson $1902,64$.

10. See Hilferding 1910; and Lenin 1916, chap. 3.

11. See Jenks 1927; and Feis 1930. 
ing agencies, recognize that such players, because they "control" the reputation of borrowers, wield considerable power, motivating study of their ideologies, beliefs, and policies. ${ }^{12}$

Yet Polanyi's and others' personification of financial markets is not methodologically straightforward. To be valid, personification requires proof that a certain group of agents is willing and able to act in a cartel or at least in a group-like manner so that it can be represented by a collective (rational) self. However, following Olson, modern scholars have been skeptical of such collusion's capacity to survive. Schultz and Weingast extend this skepticism to capital markets and cast doubt on the likelihood of successful credit embargoes in the wake of rampant free riding. ${ }^{13}$ Theoretical economists point out that lending to sovereigns is plagued by a "common agency" problem (several lenders deal with one borrower, which creates an externality in both contracting and collective action). ${ }^{14}$

Two books, published respectively by Kirshner and Tomz, have managed to do away with the role of special intermediaries that was central in Polanyi and his Marxist and populist predecessors. While Kirshner and Tomz provide different perspectives, both share the notion that lenders in the capital market are best described as atomized, uncoordinated entities, leaving no room for the powerful banking lobby of the Hundred Years Peace. ${ }^{15}$ Kirshner contends that finance wants macroeconomic stability and therefore might inhibit some conflict. Focusing on domestic financiers' attitudes and preferences regarding wars, he finds an appeasing factor in bankers' love for low inflation and policies designed to sustain it, their taste for an economy's ability to produce robust and predictable real interest rates, and so on. An appeasing bias thus appears because wars (by making nominal and real interest rates unpredictable) threaten to disrupt this favored environment. This peaceful disposition, he concludes, is an important influence in contemporary international relations and "will remain so, especially for as long as financial globalization endures." ${ }^{16}$ There is a seeming parallel between this

12. On rating agencies, see Sinclair 1994 and 2005; on the IMF, see Chwieroth 2007a and 2007b; on institutional investors see Harmes 1998 and 2001. For perspectives on the recent evolution of marketstate relations relevant to the ideas developed here, see Helleiner 1994; Strange 1996; Pauly 1997; and Mosley 2003.

13. See Olson 1965; and Schultz and Weingast 2003.

14. Early references include Eaton, Gersovitz, and Stiglitz 1986, and Bulow and Rogoff 1989, both of whom are skeptical of creditors' coordination. Compare with Wright 2002 and 2005.

15. This argument is passim in Tomz 2007. It comes explicitly in italicized form in the theory chapter entitled "Reputation and Cooperation under Anarchy" when Tomz emphasizes that his theory explains "lending and repayment even with completely atomized creditors" $(2007,226$, emphasis in original). It is also a forceful theme of the chapter "Enforcement through Collective Retaliation," which holds that "the cohesion of creditors, so central in theories of sanctioning, has had remarkably little effect on the behavior of borrowers and lenders" (ibid., 219); this theme is emphasized in the book's pitch which refers to "atomized bond markets." Available at $\langle$ http://www.stanford.edu/ tomz/ pubs/Tomz-RIC.html〉. Accessed 12 October 2011. Likewise, Kirshner 2007, 10, states: "International financial markets reflect the cumulative sentiments of uncoordinated market actors." For an earlier work sharing similar emphasis, see Aggarwal 1989 and 1996.

16. Kirshner 2007, 1. 
argument and Polanyi's (as Kirshner does recognize). ${ }^{17}$ But Kirshner accounts for the appeasing tendencies of bankers in a manner that rules out the instrumental role of certain actors-as incarnated in Polanyi's claim about particular bankers' peacekeeping action. Thus, Kirshner's view of a powerful and diffuse market antipathy against war can be seen as a post-Olsonian version of the Polanyi intuition, one where the Rothschilds and Haute Finance are missing. ${ }^{18}$

Another important recent contribution that dwells on markets' atomicity and rules out large actors and intermediaries is Tomz's study of reputation and market access. Using a historical perspective, he argues that lack of information about countries' types does align competitive and atomistic lenders' behavior and incentives. While this setting is vulnerable to free riding, it nonetheless facilitates the emergence of a certain form of discipline and permits government debt to emerge. Countries with no credit history face bad terms because they scare lenders away. They must then work hard and be patient and faithful so as to (slowly) accumulate reputational capital. Tomz provides compelling nineteenth-century evidence that new sovereign borrowers in foreign markets were penalized by high interest rates. Seasoned ones (with a good history and track record) were rewarded by lower rates. In this account there is no room for intermediaries. Tomz's very careful study does not mention Polanyi (either in the text, in the reference list, or in the index) - a suggestion that modern rational choice theory might do away with Polanyi's view that market structure (the "monopoly" of Haute Finance) mattered.

In contrast to these works, our article reconstructs Polanyi's idea, highlighting the role of intermediaries in the market for government debt. Our study is one of quality certification. Polanyi's conjecture amalgamates two complementary arguments: a monopoly power argument and a political conditionality/peacekeeping argument. We give foundations to both by introducing insights from finance and industrial organization theory, which hearken back to Michael Spence's seminal paper on the economics of signaling. ${ }^{19}$ The supply of certification services is noncompetitive. Owing to credibility issues, certification tends to exhibit features of a natural monopoly: because it earns revenues from issuing a label, a certifier can benefit from misrepresenting the true condition of the government it assessesunless such misrepresentation leads to forgoing future revenue because of reputation loss. For veracity to prevail in equilibrium, the costs of cheating (as captured by permanently diminished market share) therefore must exceed the benefits (the one-shot sale of misleading advice) obtained when certifiers own a large market share to begin with, making deviation from truthful behavior painful.

For certification to be credible there must be a critical level of monopoly powerthis explains why Polanyi could portray the global capital market as noncompeti-

17. Ibid., 9 .

18. It also stands explicitly in contrast with Hobson's insight that the "special interest of the financier" was the source of "war, militarism, and a spirited foreign policy." Kirshner 2007, 15.

19. Spence 1973 . 
tive. As we find, the Rothschilds (Polanyi's main characters and core of the Haute Finance "conspiracy") had a very large market share and were thus concerned with retaining prestige. We give both an explicit rational foundation and supporting data for this interpretation.

Next we explain why brand concerns lead prestigious bankers to distribute their seal of approval with prudence and as a result, obstruct war. Because the ability to certify rests on reputation, a prestigious certifier tailors support to countries in a way that maximizes its own prestige. Since wars increase risks and ultimately make default more likely, prestigious intermediaries seek to discourage conflict. This concern led prestigious bankers to set their face against those wars that were destructive of their future ability to certify. This is why they sought to discourage countries from military entanglements - not because prestigious bankers were some precursors of the UN or because this would look good on their vitae, but because war would have meant forgoing future revenues. We found evidence in the fact that global financing for wars was not ruled out altogether but limited to conflicts that did not threaten certifiers' brands. This new interpretation of pro-peace virtues of banking elites provides a meaningful qualification to Polanyi.

The old trinity for culpability-means, motive, opportunity-provides a detection method. Since Polanyi accused Haute Finance of having "killed" wars, we must provide evidence that prestigious bankers had the means, the motive, and the opportunity. This would be enough for most judges and juries but some may prefer a confession. Using both archival and secondary sources, we have identified cases where the relation between war and finance was explicitly discussed and, digging deeper, even found evidence of military conditionality in original underwriting contracts (which committed banks to provide funding in a stated form and time). All this is new and powerful material in support of the prestigeprotection/war-prevention nexus that we argue was at the heart of the Pax Britannica.

Because detailed studies seeking to unpack the links between IPE and security issues are rare, our new perspective on Polanyi makes three contributions. First, we make an innovative theoretical advance by showing how insights from industrial organization theory can be used in mainstream theory in international relations and IPE. Our argument explaining why political power can accrue spontaneously to private entities in situations of serious information asymmetries and enforcement problems breaks new ground. It shows that Olsonian skepticism regarding cartels' ability to survive may not be relevant when information is scant and enforcement difficult-situations that are very relevant in the real world. Likewise, our recognition of market structures' role is a challenge to institutionalist views on the role of constitutions and commitments (a view currently associated with the "democratic advantage"). ${ }^{20}$ In other words, the import of insights from diverse fields yields suggestive results and should provoke new interdisciplinary research.

20. See, for example, North and Weingast 1989; and Schultz and Weingast 2003. 
Second, our study provides both a critique and broadening of Tomz's analysis of government policy's role in securing reputation through repeat play. We show conditions under which it is profitable for the government not to wait until it has a reputation of its own but instead, to use a private agent as an intermediary to secure this reputation by proxy. Although Tomz does not consider this possibility, we show that it has empirical relevance. The result is that the intermediary acquires a form of "ownership" of government policies and can use it to secure certain policies (thus the connection with war and peace, but obviously the issue has relevance for government policies at large). Thinking of conditional lending resulting from monopolistic lenders' ownership of "property rights" over government reputation provides a theoretical foundation for why government policy may be "captured" by market actors. It also provides a theoretical explanation for why certain policy beliefs, held by private actors, are important and deserve study.

Last, our study provides new insight and reliable data to discuss Polanyi's claims. For all the popularity Polanyi's ideas have enjoyed, no such attempt has ever been made. The combination of this original data and theory also contributes to a better understanding of the nineteenth century's systems. This is useful for political scientists genuinely interested in the study of past regimes and makes historical comparisons more relevant. While today's world is no longer run by Haute Finance, we still get the insight that alternative "credibility acquiring mechanisms" are for borrowing governments like outside options for one another, suggesting that a theory of imperfect competition in conditional lending has broad empirical relevance.

\section{Was Polanyi Right? Stylized Facts About War and Market Access}

Significant anecdotal evidence has long been recognized to be on Polanyi's side. For instance, in 1859, a frustrated Italian leader Camillo Cavour reported on his difficulty in raising external capital before waging a campaign against Austria: "bankers of all countries," he lamented, "have organized a kind of conspiracy in favor of peace." ${ }^{21}$ But to go beyond the level of anecdote, new data is relevant to the question of whether capital markets discriminated against wars. We rely on a new, extensive data set of London security issues during the Hundred Years' Peace (1815-1913) that we hand-collected and matched against war data sets constructed by others. ${ }^{22}$ Our main source for conflicts is Gleditsch, who provides an update of the Correlates of War database; we rely on Reiter and Stam for information on

21. Quoted in Gille 1967, 358 (emphasis added).

22. For a description of this data set, see Flandreau et al. 2010. The data set was based on a variety of sources-including Clarke 1878; Jenks 1927; and Fenn 1883-and then checked against announcements in the press (principally The Times of London), as well as prospectuses, contracts, and archival material. 
warring nations..$^{23}$ The war data we employ coincides with what the Correlates of War database defines as "Inter-States Wars" (we added the U.S. Civil War, considering the Secessionist Confederacy as a sovereign entity). We are interested in foreign countries that managed to secure funding during wartime in the London capital market. ${ }^{24}$ That is, to assess Polanyi's claim that Haute Finance was biased against war, we produce a statistical summary of foreign countries' market access in London, and then cluster it with evidence on their being at war. The statistics have been organized to correspond to the four boom-to-bust phases in foreign debt lending in London: 1818-29, 1845-76, 1877-95, and 1896-1913. ${ }^{25}$

Table 1 reports the results that the Hundred Years' Peace is a Western European, developed-countries phenomenon. The exception is the period between 1845 and 1876, which displayed a number of "unification wars" (wars between Germany's and Italy's predecessor states on the one hand and Austria on the other, and the Franco-Prussian War-the political prelude to German unification). Apart from that, war was limited to the confines of Europe (the Crimean War) or to the rest of the world (Latin America, Asia, and North America).

When we combine this information with market access data, we obtain results that are partly consistent with Polanyi. For the entire period (1818-1913), we have nineteen instances of capital market access by foreign countries that occurred during wars, which is equivalent to 5 percent of 380 loans. For the period 18451913, which encompassed ten different wars, we find only sixteen market access events in wartime; this is only 4.5 percent of the total number of loans. Controlling for the fact that some wars received multi-access, we compute (but do not report in the table) that lending did occur during 19.6 percent of all wars. ${ }^{26}$ In other words, war lending was not a big business in London (which is consistent with Polanyi's notion of a market-place peacekeeping channel), but securing war finance was not altogether impossible, and references to automatic embargoes require further scrutiny.

Polanyi reflected that not all wars were equivalent and dismissed the Crimean war as a "more or less colonial event." Without taking a stand on specific wars, we agree that different wars had different significance depending on the belligerents' standing. In the bottom panel of Table 1, we organize London wartime loans in four categories. We distinguish: (1)“wars between powers"-wars between members of the "Concert of Europe": Austria, Britain, France, Prussia/Germany, the

23. See Gleditsch 2004; and Reiter and Stam 2002.

24. We exclude countries that secured wartime funding in other international markets (for example, Amsterdam or Paris). We also exclude funding in London of British wars (for example, the Boer Wars), since London was a domestic market for the British government. Moreover, London Stock Exchange regulations prevented countries in war with Britain to secure funding in London. Slaughter 1873.

25 . Only a few loans were made during the period $1829-45$, which would render any inferences spurious. As a result this period is ignored throughout the analysis, although the data is available from the authors.

26. The total number of wars for the period 1845-1913 was fifty-one, with lending occurring in ten, or 19.6 percent. 
TABLE 1. War and capital during the Hundred Years' Peace

\begin{tabular}{|c|c|c|c|c|}
\hline Period & $1818-29$ & $1845-76$ & $1877-95$ & $1896-1913$ \\
\hline \multicolumn{5}{|c|}{ War statistics } \\
\hline $\begin{array}{l}\text { Share of years with war in at least one country } \\
\text { Number of wars }\end{array}$ & $66.7 \%$ & $96.9 \%$ & $73.7 \%$ & $88.9 \%$ \\
\hline Between powers & 0 & 5 & 0 & 0 \\
\hline Powers vs. nonpowers & 3 & 10 & 13 & 4 \\
\hline Other wars & 3 & 11 & 4 & 9 \\
\hline Total number of wars & 6 & 21 & 17 & 13 \\
\hline \multicolumn{5}{|c|}{ Foreign issues statistics } \\
\hline \multicolumn{5}{|l|}{ Foreign issues: } \\
\hline Total number ${ }^{1}$ & 22 & 148 & 107 & 103 \\
\hline Per year & 1.8 & 4.6 & 5.6 & 5.7 \\
\hline \multicolumn{5}{|c|}{ Issues by foreign countries at war } \\
\hline Number of issues by foreign countries at war ${ }^{2}$ & 3 & 7 & 4 & 5 \\
\hline Between foreign powers & 0 & 3 & 0 & 0 \\
\hline Involving foreign powers & 0 & 0 & 1 & 4 \\
\hline Colonial wars $^{3}$ & 0 & 0 & 3 & 0 \\
\hline Other wars & 3 & 4 & 0 & 1 \\
\hline Number of issues from countries not at war & 19 & 141 & 103 & 97 \\
\hline Share of war loans & $14 \%$ & $5 \%$ & $4 \%$ & $5 \%$ \\
\hline
\end{tabular}

Notes: 1. Outright foreign issues on the London market (no conversions). Foreign powers include Austria, France, Germany/Prussia, Italy, and Russia; Japan is not treated as a power. See text for description of sources for loans.

2. From Gleditsch 2004, who revises the Correlates of War database. We focus on so-called interstate wars (ibid., Tab. A, 248-49). Loans from "war countries" are those issued during wartime. We exclude issues that are issued before or after wars as well as indemnity loans (that is, French 1871-72 loans).

3. Colonial wars are those involving foreign powers or countries in a colonial conquest.

Source: Author calculations from a variety of sources.

Russian Empire, to which we add the Kingdom of Sardinia/Italy; ${ }^{27}$ (2) "wars involving powers" (where at least one power was involved but they did not fight one another); (3) "colonial wars" (all that the name implies); and (4) "others" (a residual category that includes the few wars between countries outside the nations mentioned, such as conflicts between Latin American nations).

The category "wars between powers" is expected to have more significance in terms of geopolitical stability and should be more rationed than the other types of war. To see whether this pattern obtains, Table 1 clusters market-access events according to war types. ${ }^{28}$ With only three exceptions (the 1854 and 1855 Crimean War loans to Turkey and a 1870 Franco-Prussian War loan to France), wars between

27. Incidentally, applying this criterion makes the Crimean war, in which Britain and France, alongside the Ottoman Empire, fought Russia, not a "colonial event" (as Polanyi's suggested) but a "war between powers."

28. We consider the market access event according to war type, not borrower type. In this logic, Ottoman borrowing during the Crimean War is a loan for a war between powers, because Britain and France were actively supporting the Turks against Russia. 
powers never led to international loans in London. International finance abstained from funding the German and Italian unification wars, justifying Cavour's concern that his political efforts were obstructed by bankers.

As Table 1 shows, the bulk of war loans concentrated on other types of conflicts. There were only two "wars involving powers" during which the London capital market was used: the Russo-Turkish War of 1877-78 (for one loan) and the Russo-Japanese War of 1904 (for a total of five loans). There were also two colonial wars during which the "colonized" country received funding from London (China against France in 1885 and China against Japan in 1894-95) for a total of three loans. Four other wars involved five loans from London: the ArgentinaBrazil-Uruguay skirmish of 1852, the Triple Alliance War against Paraguay of 186570, the U.S. Civil War, and the second Balkan War. Our findings thus both vindicate Polanyi's hypothesis and qualify it. That certain types of wars were penalized is not consistent with Polanyi's interpretation of financiers providing a public good. Had they been a peacekeeping body they ought to have been willing to prevent all wars. They did not.

\section{The Argument: Prestige as Gatekeeping}

\section{Economics of Prestige}

Our explanation of how and why markets discriminated against certain wars is an argument about the role of prestige in certification. It has roots in industrial organization and financial economics research that has explored conditions under which markets can solve problems involving incentives to report truthfully. For simplicity, consider a world in which there are two types of investors (informed and uninformed) and two types of governments (good and bad). As in the respective works of Kirshner and Tomz, ordinary investors suffer from information asymmetries. Assume, for example, that such investors-unlike informed intermediaries (underwriting banks) — cannot distinguish the relative merits of borrowing governments. Intermediaries have incentives to cheat investors because they earn fees, but investors understand that.

As we argued in earlier, related work, one possible solution of such a setting is an arrangement where bankers are sorted into a pyramid of prestige (the less numerous, more prestigious bankers are at the top) and association of a given loan with prestigious bankers sends a quality signal. ${ }^{29}$ The reason is that security underwriters' reputation for veracity helps them secure a large market share. This mitigates the moral hazard problem in the production of information. Prestigious intermediaries who might otherwise be tempted to overprice securities (to generate shortterm gains) are held back by their very prestige: if they lose it, they will damage

29. See Flandreau and Flores 2009 and forthcoming. The modern theory of signaling was pioneered by Spence 1973. He showed how efforts could be used to signal a potential employee's worth. 
future revenues. ${ }^{30}$ An important theme in economic models resting on such ideas is that market share emerges as the endogenous solution to problems involving precommitment or credibility. A few prestigious bankers have monopoly power and specialize in high-grade securities, while the many ordinary underwriters are competitive and deal mostly with low-grade securities (they have a narrower market, plagued with rampant quality problems).

While the recent "subprime" crisis (a major gatekeeping failure) has cast doubt on the validity of related arguments in modern markets, our earlier work on foreign debt found substantial support. During the first foreign debt boom of the nineteenth century, when the London market for foreign debt was started, the House of Rothschild surpassed all other underwriters in terms of market share, capital stock, and performance. This is consistent with our notion that prestige was used for the successful origination and distribution of high-quality ("investment grade") government securities.

\section{Prestige Meets International Relations}

The Rothschilds' large market provided them with incentives for being reliable. ${ }^{31}$ The House of Rothschild consistently held the top position in the "league tables" of foreign government debt. And to retain this leadership, a prestigious originator ought to issue successful securities. Flandreau, Flores, Gaillard, and Nieto-Parrà show that the Rothschilds did outperform competitors on this score throughout the entire Hundred Years' Peace. ${ }^{32}$

The only other bank that featured in the top three (in three subperiods out of four) is the House of Baring, which historians reckon was the other prestigious house. ${ }^{33}$ Unsurprisingly, during the entire period, the market remained concentrated-market shares for the top three loan originators were always above 50 percent. Computation of so-called Herfindhal-Hirschmann Indices (HHI) (which capture the degree of concentration) support this: indices range from concentrated to very concentrated according to conventionally accepted thresholds. ${ }^{34}$ Therefore, the degree of concentration and persistence was remarkable and confirms

30. See Chemmanur and Fulghieri 1994 for a model. Empirical studies include Megginson and Weiss 1991; and Carter and Manaster 1990 on the role of reputation in initial public offerings. Carter, Dark, and Singh 1998 find that issues managed by prestigious houses outperform those managed by ordinary ones; Beatty and Ritter 1986 test for the proposition that originators whose issues underperform lose market share.

31. See Flandreau et al. 2010 for details.

32. See ibid.; and Flandreau and Flores forthcoming.

33. See Hidy 1949; Chapman 1984; and Ziegler 1988.

34. HHI are as follows (we omit the period 1825-45: there were almost no issues, and most of the few that took place were conversions): $1818-25: 2,432 ; 1845-76: 1,382 ; 1877-95: 2,176 ; 1896-1913$ : 1,196. It is conventionally reckoned (for example, for regulatory purposes) that markets in which the HHI is below 1,000 are fully competitive, those between 1,000 and 1,800 points are concentrated, and those in which the HHI is in excess of 1,800 points are highly concentrated. 
our view of an equilibrium outcome with market leadership reinforcing, and being reinforced by, prestige.

In short, prestige was a strategic investment (sunk cost) that created a barrier to entry against other banks. The sunk cost provided a kind of monopoly power that did not rest on standard cartelization (that is, a mere agreement between market participants) and was thus not subject to free riding, contrary to the conventional concern of Olson and others. For instance, our characterization differs from the Marxist interpretation of Polanyi's Haute Finance as some kind of "gang." The Rothschilds were special not because they were the "boss" of a cartel but because they differentiated themselves from all the other issuers through quality signals. The bankers' name was a prestige good-something which Polanyi (as a precursor of economic anthropology) might have appreciated-but he did not articulate it.

Our interpretation of monopoly power stemming not from cartelization but from prestige is novel..$^{35}$ In standard models, bondholders' attempts to coerce defaulters are hampered by the bondholders having their money tied with the defaulters (thus creating a conflict of interest and time inconsistency). But delegation of enforcement to a prestigious underwriter does not present this flaw. Once a loan has been issued, the investors rather than the prestigious bankers bear the cost of default. Since bankers have already disposed of the loan, they mostly worry about their ability to certify future loans which rests in part on wise ex ante choices but even more so on successful ex post trouble-shooting. For this, they do not hesitate to use credit embargoes. In other words, prestigious bankers can credibly precommit to punish defaulters in the future (because punishing defaulters is really polishing the bankers' shield). ${ }^{36}$

For this reason the prestigious bank has a valuable role to play. When a borrower's reputation can rise and fall, certification by prestigious houses (whose market share and prestige is stable) provides a dependable anchor. One obvious situation when a country lacks credibility is when it is new in the market. At a broader level, however, the need for a reputable underwriter can arise each time a country undergoes some "information crisis." A fiscal crisis is one possibility. The prospect or outbreak of a war (with its dire fiscal, political, and diplomatic complications) is another. Economists have shown abundantly that wars were historically a major source of deficit. ${ }^{37}$ This means that the certification power of prestigious intermediaries becomes extremely valuable during diplomatic crises and military conflicts.

That wars increase information asymmetries and thus increase the value of prestige is one thing. But what prevents prestige from sponsoring a war? The invisible

35. The importance of underwriter prestige has been neglected in recent research. Exceptions include business history. See Gille 1965 and 1967; Roberts 1992; and Suzuki 1994. In political science, the work of Mosley 2003 is the one exception although she does not relate it explicitly to conditional lending.

36. See Flandreau and Flores forthcoming for an empirical study.

37. Barro 1987. 
hand at work here is the underwriter's concern about retaining its good name. ${ }^{38}$ Wars were hazards. They increased reputational risks. Thus war was seen by prestigious banks as a direct threat to their charters. Reflecting this, in the late 1830s when the Rothschilds were asked to lend to Belgium, which refused to make peace with Holland, private correspondence shows precisely this motive for the Rothschilds' decision to turn down the loan application: "our good will does not go as far as giving them a stick for them to kick us with [by funding them when they want to wage a war], that is to say giving money to make a war and destroy the credit which we support with all our forces and resources." 39

\section{Banker Prestige Versus Country Reputation}

Tomz considers a Polanyi-free world where desire to borrow cheaply provides incentives for borrowers' cooperation with lenders. ${ }^{40}$ Countries make efforts to repay their debts to accumulate reputational capital. While they cannot directly observe government characteristics, investors do observe whether governments discontinue interest service and collect data about the circumstances they face. Because investors try to infer countries' types from behavior, the debt of "new" borrowers is discounted (they have no track record). But as borrowers become "seasoned" (conditional on their paying), they gradually secure better terms because investors update prior beliefs. The process through which upgrades or downgrades occur also takes into account current circumstances and is thus known as "contextual inference": servicing one's debt in an unfavorable environment has more value for investors than the same decision undertaken in a favorable environment.

The world we consider is one in which investors use the signals from certain prestigious brands to make inferences about countries' types. Investors cannot tell which countries' debt would be a good investment, but they know that credible delegated monitors have that knowledge and the capacity to enforce; hence investors react not to news about a country's behavior but rather to the presence (or absence) of a prestigious underwriter. In practice, we predict that investors' market power is an increasing function of the extent of information asymmetries. The less that agents know about the borrowing country, the more that prestigious bankers add value. At the extreme, if investors know close to nothing then a prestigious bank's market power is maximal. Unlike Tomz we recognize that, in situations of severe information asymmetries, countries have strategies other than patience (waiting to build a reputation "by hand"). They can use the certification services of market gatekeepers. But we saw that wars increase risks, information asymmetries, and thus the need for certification. To paraphrase Ford, countries facing a war cannot build a reputa-

38. Evidence in Flandreau and Flores forthcoming shows that the Rothschilds had very few defaults (the lowest rate of all significant underwriters). Even when there was a credit event for a security they had sponsored, they saw to it that investors would receive the promised returns and beyond.

39. Gille 1965, 298 (emphasis added).

40. Tomz 2007. 
tion on the fact that they are going to win: this is the highway along which prestigious financial gatekeepers become gatekeepers of war, too.

\section{The Value of Bankers' Certification}

\section{Evidence from a Case Study}

Prestigious banks could inflict penalties on countries that adopted policies they disliked. Because prestige added substantial value, refusing support entailed costs. One way to see how much value could be added or withdrawn is to consider the example of an upgrade, such as when a government was lucky to move from an ordinary to a prestigious underwriter. The resulting variation in "interest rate spreads" (that is, returns required by investors to hold the bonds minus returns on risk-free British bonds) is a measure of prestige's effect. The experience of Brazil in 1825 provides a suggestive entry. An initial public offering in the London market had been managed by a consortium of houses led by Wilson, an "ordinary" merchant bank. ${ }^{41}$ The Wilson issue (at $75 £$ per security, on 18 August 1824) turned out to be a failure. ${ }^{42}$

A few months later however, the London Times revealed that the Rothschilds would underwrite the balance of the loan at $£ 85$ per bond. A careful examination of the press shows there had been no "news" regarding Brazil during the period: the only innovation was the House of Rothschild getting involved. The Times explained that this event had caused bond prices to start rising in the last few weeks in the "belief that the contract for the remainder would fall to the eminent capitalist who is now understood to have taken it.... [Rothschild's] remarkable success in raising the credit of some of the European Governments by his contracts for loans in England is the best guarantee to a similar result on the other side of the Atlantic, and there seems little cause to doubt that the Government securities of Brazil will, under his auspices, bear as high quotations in the money market as any of the continental States." 43

Figure 1 organizes evidence on Brazilian securities by showing weekly data for their yield spreads. As controls, we show like data for securities of other Latin American securities (Colombia and Buenos Aires, that is, Argentina). The figure also indicates the period during which rumors were reported to be lifting the price of Brazilian securities. ${ }^{44}$ The signal sent by the news of association with the Rothschilds was worth a 50-100 basis points reduction in Brazilian yield spreads. ${ }^{45}$ In

41. See Chapman 1984; Dawson 1990; and Flandreau and Flores 2009.

42. See Dawson 1990; Flandreau and Flores 2009; and Rothschild Archive, 000/401A/7/7.

43. London Times, 12 January 1825, 2. See also Dawson 1990, 93; and Rothschild Archive, Memorandum with Brazilian Government, 1825.

44. The data come from the "Foreign Funds" section of the London Times. Accessed via The Times Digital Archive, 1785-1985.

45. Both prices and qualitative evidence show the improvement was sustained. As one referee pointed out, in Figure 1, all spreads stop declining at the same time, not just the Brazilian one-the Roth- 
other words, the name of prestigious houses was a very valuable collateral. It is not that countries could not issue without them (although we remark that the Wilson issue failed) but they would issue less and/or at more expensive costs. Prestigious banks have something to give to (and thus withhold from) policymakers.

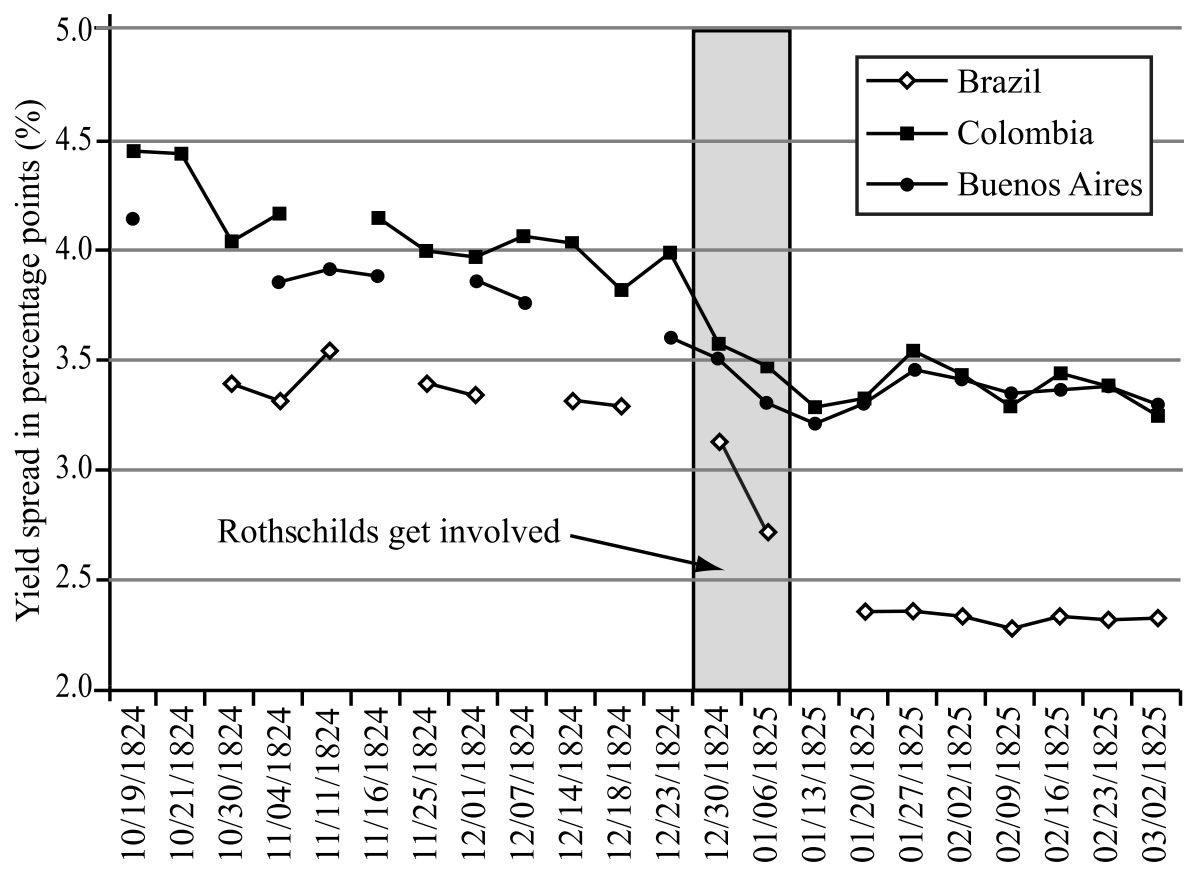

Source: "Foreign Funds" section of The Times; Rothschild Archive 000/401.

FIGURE 1. Weekly yield spreads on Latin American securities for three states

\section{Countries' Reputation Versus Certifiers'Prestige: Cross-Section}

To further investigate the value of prestige, we now compare the effect of prestige (use of prestigious bank as signal) and that of patience (time on the market). Table 2 organizes the evidence, focusing on the period $1845-77 .{ }^{46}$ We compare the yield

schilds might have had any effect in this through some form of "contagion." In this case our measure would underestimate a Rothschild's true effect - the Rothschild effect may be even bigger than we suggest.

46. During this period, the debt market was mature enough that the performance of underwriters must have been common knowledge even to poorly informed market participants; and there were many new borrowers, thus enabling us to make statistically reliable inferences. 
premia at issue (a measure of risk) for "new" and "seasoned" borrowers and then control for prestige. "New" issues refer to countries borrowing for the first time in the London Stock Exchange during the period. ${ }^{47}$ To capture the quality of the seasoning process, we distinguish "clean" issues - those without a record of default or renegotiation-from "tainted" ones (the others). ${ }^{48} \mathrm{New}$ issues can be tainted if the issuing country inherits a default record from a previous entity to which it is related. ${ }^{49}$ The table is intended to address whether prestige enables the securing of good terms independent of seasoning.

We first look at the "pure effect" of seasoning and government honesty ("All banks" column). Results are fully consistent with Tomz's forbearance hypothesis. ${ }^{50}$ We find that within each category, new borrowers were discounted. New clean issues exhibited spreads that were about 200 basis points higher than their seasoned counterparts, and the gap between new tainted issues and seasoned tainted ones is larger still (about 260 basis points). There is also a 160 basis-points reward from having been seasoned without experiencing a default.

Consider now the marginal effect of prestige. We add a Rothschilds column that replicates the same exercise but for Rothschilds' loans only. As seen, the involvement of the Rothschilds creates value in several critical groups. For new clean bonds, the Rothschilds' yield premia are about 300 basis points lower than average for the category. This is an enormous effect: the Rothschilds could bring new borrowers to the market at very attractive terms.

Seasoned tainted issues when they were taken in by the Rothschilds also enjoy a reduction of 100 basis points, meaning that prestige could restore credit. ${ }^{51} \mathrm{We}$ conclude that, consistent with our intermediary-based certification hypothesis, prestige made a considerable difference. Countries had other ways-beyond patience and effort—of addressing the problem of asymmetric information.

Finally, the Rothschild effect is not substantial for seasoned clean issues. This result is unsurprising but important. The marginal gain from association with prestige is smallest for countries that already have a good track record: these are the ones facing the smallest information asymmetries. The inference is that the greater the asymmetry of information, the more valuable the prestige.

47. As a result, subsequent issues by the same "new" borrower are treated as new. Results are not affected if instead we exclude subsequent issues by the same borrowers.

48. We make no effort to control for how serious the breach of faith was.

49. For example, countries that initially formed the "Great Colombia" (Venezuela, Ecuador, and Colombia) or Guatemala (later Guatemala, Costa Rica, and Honduras) first accessed the market during the period under study as successor states of previous defaulters. We placed Hungary in the new tainted group because it was a successor state of Austria, which had imposed a capital levy in 1867 (and despite Hungary's attempt to indemnify bondholders for its predecessor's harm). See Köver 1988; and Flandreau 2003.

50. Note that Tomz's test differs slightly from ours. He distinguishes "new" from "seasoned" borrowers by looking at the date for the first loan in the Amsterdam market after 1695 and then reports average market yields in 1824 and 1825 (Tomz 2007, tab. 3.3). In contrast, we look at primary market yield premia.

51. The Rothschilds unsurprisingly endorsed no new tainted issues at all. 
TABLE 2. Seasoning versus signaling, 1845-77

\begin{tabular}{lcc}
\hline & All banks & Rothschilds \\
\hline Number of loans & 132 & 20 \\
Total amount (£ million) & 965,232 & 420,486 \\
Total amount (\%) & 100 & 43 \\
$\quad$ Yield spreads on foreign & government issues (\%) \\
New $\quad$ & \\
$\quad$ Clean & 4.78 & 1.72 \\
$\quad$ Tainted & 5.65 & N.A. \\
Seasoned & & \\
$\quad$ Clean & & 2.39 \\
$\quad$ Tainted & 3.44 & 3.06 \\
\hline
\end{tabular}

Notes: Prices of U.K. consols are from The Times. Yields calculated via the standard coupon/price formula. Database for loans described in Flandreau, Flores, Gaillard, and Nieto-Parra 2010. Underwriters (that is, lead managers of the issues) were identified by using contracts found in archives, the press, and prospectuses. Spreads computed using date of issue and yield on consols at the end of the month of issue. In the few cases when the month of issue is not known, we used year-end consol yields. We exclude conversions of loans. Because France's loan of 1871 was unusually large, we have also computed results without it. Results give 2.43 (new clean) and 2.36 (of which: Rothschilds), thus not significantly affecting results. N.A. = not applicable. See text for sources.

\section{Countries' Reputation Versus Certifiers' Prestige: Time Series}

The previous section discussed how the effect of prestige on clean seasoned countries is reduced. However, because such countries with loans underwritten by the Rothschilds were not the same as those underwritten by the rest, it is not possible to make strict pairwise comparisons. ${ }^{52}$ A useful complement to Table 2 is Table 3, which organizes a test of differences in bond spreads following a switch in underwriters. This approach has the advantage of controlling for country characteristics. According to our theory, when a country switches from the Rothschilds to an ordinary underwriter, spreads ought to rise (for this is a downgrade). Conversely, if it switches from a lesser firm to Rothschilds, then spreads ought to decline (upgrade). Not all switches are equivalent. A changeover from the Rothschilds to

52. A large part of the non-Rothschilds' seasoned clean issues is provided by Scandinavian countries (Denmark, Norway, and Sweden). These loans typically represented smaller amounts so that liquidity requirements were less. The Rothschilds' seasoned clean issues tended to be bigger. An example is France's indemnity loan that amounted to about 10 percent of France's gross domestic product (GDP), dwarfing the Scandinavian issues. The yield spread was about 3 percent. This was greater than the average Scandinavian yield spread but the relevant comparison is the spread France would have faced had the issue been underwritten by ordinary houses. Klovland 2005 reports evidence suggesting that Scandinavian states thought that, on occasion, they would have issued on better terms, had they been able to use Rothschild services. 
another house with a good standing is less significant than a changeover to a very "ordinary" one. There is no clear consensus on the precise ranking of all firms but previous work emphasizes the difference between the Rothschilds and the Barings on the one hand, and "the rest" on the other. ${ }^{53}$ As a result, Table 3 distinguishes between switches depending on their being with the Barings or with another "ordinary" house.

TABLE 3. From and to Rothschilds: Underwriters' upgrades and downgrades for seasoned countries, 1850-73

$\begin{array}{cccc}\text { Country } & \begin{array}{l}\text { Year of } \\ \text { switch }\end{array} & \begin{array}{c}\text { Previous } \\ \text { loan }\end{array} & \begin{array}{c}\text { Change in spread } \\ \text { (basis points) }\end{array}\end{array}$

Upgrades from:

Clean countries

\begin{tabular}{|c|c|c|c|c|}
\hline \multicolumn{5}{|l|}{ 1. Ordinary } \\
\hline Goldsmid & Brazil & 1852 & 1843 & -105 \\
\hline Hambro & Sardinia & 1855 & 1851 & -212 \\
\hline Dent, Palmer \& Co. & Turkey & 1855 & 1854 & -359 \\
\hline Hambro & Italy & 1863 & 1862 & +27 \\
\hline Morgan $^{1}$ & France & 1871 & 1870 & -98 \\
\hline Average & & & & -150 \\
\hline \multicolumn{5}{|l|}{ 2. Elite } \\
\hline Baring, Hope & Russia & 1862 & 1860 & +38 \\
\hline Baring, Hope & Russia & 1870 & 1869 & -13 \\
\hline Average & & & & +13 \\
\hline \multicolumn{5}{|l|}{ Downgrades to: } \\
\hline \multicolumn{5}{|l|}{ 1. Ordinary } \\
\hline Dent, Palmer \& Co. & Turkey & 1858 & 1855 & +324 \\
\hline Gen. Credit \& Fin. Co. & Italy & 1865 & 1863 & -70 \\
\hline Average & & & & +127 \\
\hline \multicolumn{5}{|l|}{ 2. Elite } \\
\hline \multirow[t]{2}{*}{ Baring, Hope } & Russia & 1864 & 1862 & +48 \\
\hline & \multicolumn{3}{|c|}{ Tainted countries } & \\
\hline \multicolumn{5}{|l|}{ Upgrades from (ordinary) } \\
\hline Morgan & Spain & 1870 & 1869 & -389 \\
\hline \multicolumn{5}{|l|}{ Downgrades to (ordinary) } \\
\hline Spanish Financial Commission $^{2}$ & Spain & 1870 & 1870 & +384 \\
\hline
\end{tabular}

Notes: 1. Rothschilds issued the next loan (upgrade) jointly with Barings.

2. The Spanish Financial Commission was a representative body of the Spanish Ministry of Finance. The issue referred to was distributed directly on the market.

Source: Authors' computations; see text for details.

Table 3 (which distinguishes among clean and tainted issues) shows that when there is a switch between the Rothschilds and an ordinary underwriter, big gains

53. As measured by market opinion and the stock of capital. See Chapman 1984; and Flandreau and Flores 2009. 
or losses are observed regardless. This obtains for both the clean and tainted group. For clean countries, the variation is 150 or 127 basis points, either way. The effect of prestige is naturally greater for tainted countries as illustrated by the case of Spain (about 400 basis points either way). ${ }^{54}$ This is in contrast to transition between elite underwriters (Baring and Rothschild), which does not seem to have caused big changes. Thus, clean countries could, at the margin, leave the best underwriter in favor of the other reputable one. This is where and how a country's selfcertification-namely, establishing itself as a good (clean) borrower-could compete against a banker's seal of approval: the Barings' entry threat to the Rothschilds coerced the Rothchilds into providing good countries with good terms.

In the end, the prestige of bankers was a bandage on information asymmetries. This helps explain how, when wars occurred, the uncompetitive nature of the market for government debt became even more marked. Countries desperately needed prestigious bankers' seal of approval because in wars, countries came probably closer to the tainted benchmark. The conclusion is that the Rothschilds' political leverage was particularly large before and during wars.

\section{Unpacking Polanyi: The Microeconomics of Peace and War}

\section{The War that Was Not: Belgium 1830-39}

Having found the weapon (or means), a motive, and an opportunity, we are close to indicting Haute Finance on the charge that they willingly interfered with wars. But the problem is that we have failed so far to "catch them red-handed." Indeed, since there was no body-like the dog that did not bark (Sherlock Holmes: "That was the curious incident") —-we are grappling with the curious incident of wars that did not happen. Fortunately, there are cases where the nonoccurrence of a war can be traced to the banker's action. We focus on the international crisis that developed between the 1830 independence of Belgium to the peace treaty with Holland in 1839, during which policymakers feared that a war was imminent.

The proximate cause of the crisis was the Belgian Revolution of 1830, which led to the new state's proclaimed independence from Holland on 4 October 1830. The Belgian uprising signaled a resurgence of French influence and renewed political tensions between France and the other powers. It challenged the borders established by the Congress of Vienna in 1815. An international parlay group (the London Conference) was created in November 1830 and led to the recognition of Belgium's independence from Holland by "foreign powers" (Austria, Britain, France, Prussia, and Russia) in January 1831. Belgium secured a constitution on 7 February

54. Note that the Rothschilds' loan to Spain in 1870 was serviced throughout its entirety and was excluded from all subsequent restructuring of Spanish debts. In modern language, Rothschild securities had "mezzanine" status. 
1831, and a king (Leopold I) on 21 July 1831. In August 1831, however, King William of Holland rejected Belgium's claim of independence and marched toward Brussels. French intervention (not under the London Conference's mandate and thus a threat to peace) compelled the Dutch to evacuate Belgium late in 1831, leading to an international treaty (15 November 1831$)$ to be ratified by the five powers. Belgian claims for further territorial expansion, and the resistance of the Dutch king delayed ratification by Austria, Prussia, and Russia (they would not recognize Belgium's independence as long as the Dutch did not recognize it either). In fact, in late 1831, contemporary observers did not rule out Prussia's intervention to support Holland. ${ }^{55}$ Russian and Austrian policy-makers were managing situations with subject or neighboring countries and hated the notion of Belgian selfdetermination. The stalemate extended until May 1833 (when the Dutch king and his allies recognized Belgium's existence). But it was not until April 1839 that the final Dutch-Belgian separation treaty was signed.

Haute Finance did play a role in preventing the conflict from erupting. Before the Dutch intervention, the provisional Belgian government started negotiations with the House of Rothschild to issue a loan. But the Rothschilds were reluctant to lend before a diplomatic solution was found. ${ }^{56}$ Their response was to include explicit war conditionality in the international loans made during that period. That is, they introduced clauses subjecting the loans to peaceful policies. The most commented-upon condition was Article 9 of the first international loan issued by Belgium, signed on 19 December 1831. The press and subsequent scholars have referred to it as intending to prevent war between Belgium and Holland. We retrieved the actual contract in the Archive of the House of Rothschild and discovered that the condition (reproduced in Figure 2) was not about war between Belgium and Holland. ${ }^{57}$ Since Belgium and Netherlands were formally already at war, the contract could not forbid war. And since the Rothschilds did not have any leverage on Holland, which did not borrow, the contract could not require Belgium to make peace since this would also depend on Dutch behavior. Instead, Article 9 of the contract (which contained the conditionality clause) gave underwriters the right to reduce or suspend lending in case of military intervention by one power outside of the mandate of the London Conference. ${ }^{58}$ Politically, the clause achieved two things. It automatically deterred Belgium's efforts to involve France in the conflict and aligned its incentives with peace. It can also be thought of as a monitoring device designed to keep the London Conference together.

The reduction or suspension of actual lending was both an effective and credible deterrent because installments from loans were spread over time (they could

55. See "Express from Paris," The Times of London, 6 August 1831, 3; and Gille 1965, 212.

56. Gille 1965, 221.

57. Contract of 19 December 1831, Rothschild Archives, Roubaix, 132 AQ 38.

58. Precisely the circumstance triggering retaliation by lenders was: "Belgium and Holland being at war, one of the five Great Powers would intervene in this war in an other way than in the name and with the authorization of the London Conference." Rothschild Archives, Roubaix, 132 AQ 38. 


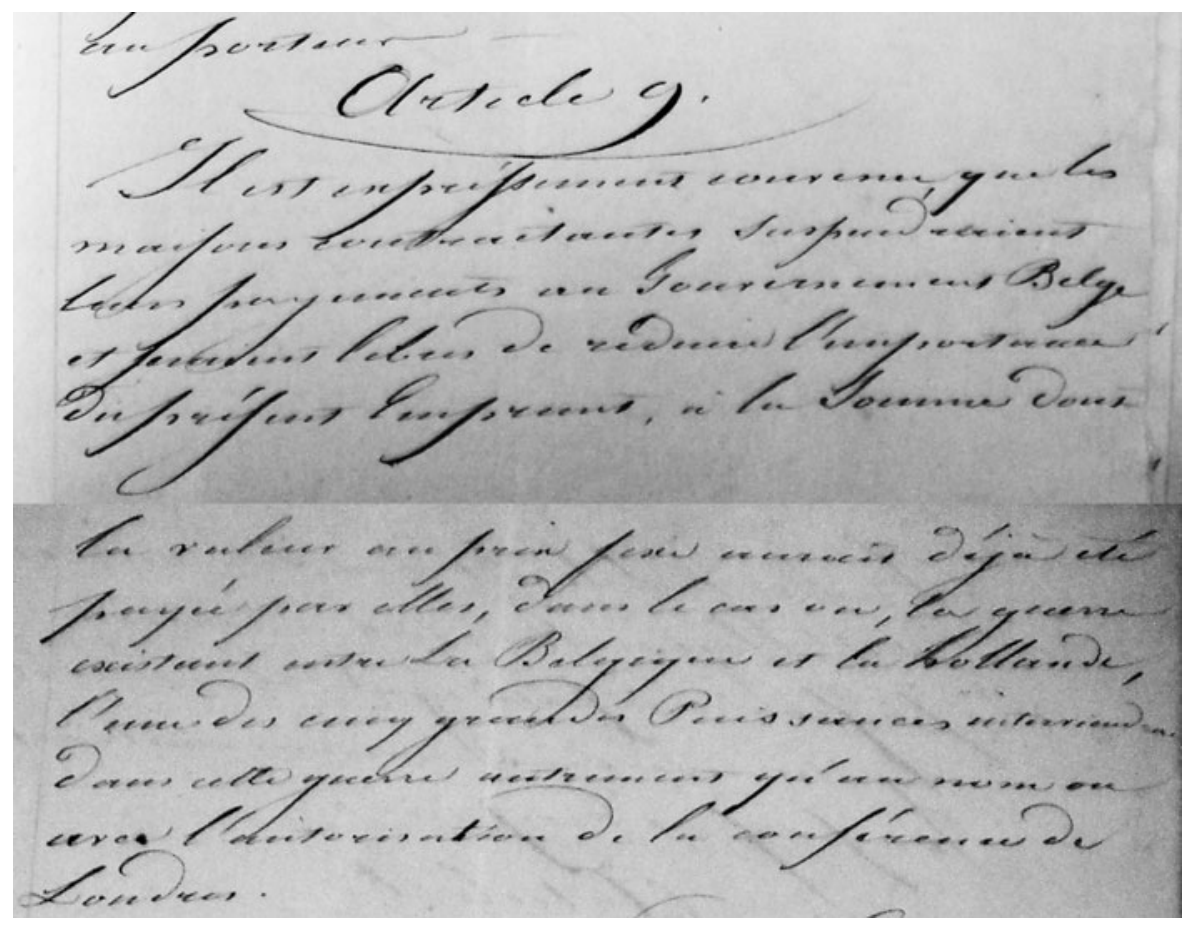

Notes: Text reads: “Article 9. Il est expressément convenu que les maisons contractantes suspendraient leurs paiements au gouvernement belge et seraient libres de réduire l'importance du présent emprunt à la somme dont la valeur au prix fixé aurait déjà été payé par elles, dans le cas où la guerre existant entre la Belgique et la Hollande, l'une des cinq grandes puissances interviendraient dans cette guerre autrement qu'au nom ou avec l'autorisation de la conférence de Londres." Translation: "It is unreservedly agreed that contracting houses would suspend transfers to the Belgian government and would be free to reduce the importance of the stated loan to an amount corresponding to payments already made at the agreed upon price, in the event where, there being war between Belgium and Holland, one of the five great powers would intervene in this war in another way than in the name or with the authorization of the London Conference."

Source: Rothschild Archive, Roubaix, 132 AQ 38-39.

FIGURE 2. Military conditionality: Article 9 in the Rothschild-Belgium contract of 19 December 1831

extend over several months) and thus permitted close monitoring. ${ }^{59}$ Belgium also was not the only nation on watch. During the Belgian insurgency, the London press contained repeated discussions of the Rothschilds implementing war condi-

59. See "Money Market and City Intelligence," The Times, 24 December 1831, 2, for a discussion. The Rothschilds also split the loan in two subsequent issues, thus giving themselves time to see how the situation would play out. Last, by making sure that the public would know of this clause, the Rothschilds ensured that a tight correspondence would be created in the minds of investors between the adoption of peaceful ways by nations and their standing in the capital market. 
tionality. As markets grew nervous, the value of the Rothschilds' seal of approval increased, which they took advantage of to lobby all interested parties into a peaceful resolution of the crisis. In March 1831, a loan to Austria included an explicit no-war condition. ${ }^{60} \mathrm{~A}$ loan to France in April 1831 required its finance minister to publicly announce France had no war purposes. ${ }^{61}$ As the situation deteriorated, a loan request by Russia in late 1832 was turned down because of concern it would serve to fund a war and skepticism about Russia's ability to precommit. Discussion in the Times provides important insight into the motives that deterred prestigious banks from lending to a country considering war, namely that the prestigious house would harm itself through the increased risk on the other loans it had previously sponsored: it would be to the "houses of the first class in the city of London, those of Rothschild and Baring ... probably more injurious to assist in such a project, by the consequences it would have on their other investments, than any gain by the contract itself could compensate for." ${ }^{62}$ The discussion went on to argue that if the prestigious houses were to lend, they would do it conditionally: "[The lending house] would require explicit assurances, or pledges, from the Russian Government that war was not in the most distant contemplated." ${ }^{63}$ There was skepticism that Russia's pledge to peaceful attitudes would be credible. In a subsequent article the newspaper added that only "houses of less note appear to be wavering about ... acceptance" of issuing the loan, since they did not face a reputational risk. But the writer argued that it was unlikely these houses could issue the loan on account of their being too ordinary to convey valuable signals in a difficult market. ${ }^{64}$ Taken between the rock of prestigious banks' rebuttal and the hard place of the harsh terms and uncertainties of a loan with a lesser house, the Russian "Ambassador [had] no alternative but to wait till it is made apparent to the dullest capacity that his government means honestly, and that the danger of a continental war is removed by the settlement of the Belgian question." 65 The Times thus predicted that "the Russian Government, if really requiring such loan for pacific purpose, would find it so much for its interest to wait till the affair of Holland and Belgium is disposed of, that the very pressing it now would carry with it the suspicion of bad faith in that respect, etc." ${ }^{\circ 6}$ Obviously, if Russia really needed money, it was encouraged to put its political weight into supporting a swift and pacific resolution of the Belgian crisis.

The Rothschilds continued to apply pressure on the Belgians afterward: while war had been avoided, peace was not yet signed and the Belgians fiercely refused giving up territorial claims. To escape the conditions imposed by the Rothschilds, the Belgians tried to issue a loan in their own market, without the Rothschilds, but

60. Gille 1965, 216.

61. "Money Market and City Intelligence," London Times, 22 April 1831, 4.

62. "Money Market and City Intelligence," London Times, 1 December 1832, 4 (emphasis added).

63. Ibid.

64. It is "clearly impossible for them [the ordinary houses], at such time as this, to conduct an operation of that nature." "Money Market and City Intelligence," London Times, 3 December 1832, 4. 65. Ibid., 3.

66. "Money Market and City Intelligence," London Times, 1 December 1832, 4 (emphasis added). 
failed. ${ }^{67}$ Mounting financial needs in the late 1830s provided the Rothschilds with an opportunity to resolve the matter. In 1838 the Belgians needed to access markets again and a new loan had the peace conditionality clause in the same language as in $1831 .^{68}$ Faced with continued Belgian resistance to signing a peace treaty however, the Rothschilds openly refused to lend in 1839. Pressure mounted until the government was coerced into signing the final settlement of the peace treaty. The signature was tied to the provision of two short-term "treasury note" loans (both concluded in March and April 1839). The short maturity ensured Belgiums would not have second thoughts. According to Gille, the issue of the treasury notes had a clause that again conditioned the supply of funds on the pursuit of peace. ${ }^{69}$ Insider sources from the Rothschild house show that one Belgian representative had (not too adroitly) boasted that if only the "Rothschilds were to agree to give us 30 millions, then we shall not care for France and Britain and will obstruct [peace]." ${ }^{70}$ This is evidence that conditionality was a factor in securing peaceful outcomes. Reporting upon the episode to Chancellor Metternich, the Austrian ambassador concluded that "the House of Rothschilds has rendered a new distinguished service to the cause of order and peace."71 This makes of the Rothschilds a delegated monitor of the Vienna Peace, and we have explained why they would and could play that role.

\section{The Wars that Were: A Study of Military Funding 1845-1913}

Table 4 organizes relevant evidence on war loans to assess who received funding from whom and at what price. We provide information on the fifteen wartime capital-market access events identified for the period 1845-1913. The table distinguishes between types of wars in the same way as Table 1 (wars between powers, wars involving powers, colonial wars, and others). For each loan, we identify the underwriting bank, the yield spread at issue, and a benchmark yield spread for average or typical previous peacetime issues. We report information on estimated casualties, an indicator of violence. Finally, we report an estimate of the market "discount," the price difference between the loan's issue price and the secondary market price of a comparable one, a measure of information asymmetries. ${ }^{72}$

67. In particular, an attempt at tapping markets directly in 1836 for a 30 million Belgian Francs loan that was sometimes hailed as a success (it was initially oversubscribed) turned out to include an overwhelming share of purely speculative subscriptions. In order to prevent prices from plunging, the government had to intervene and was reported to have owned at one point close to two thirds of the subscription. Depouhon 1840, 248.

68. Contract of 17 June 1838, Rothschild Archives, Roubaix, 132 AQ 38.

69. See Gille 1965, 299; and Bouvier 1992, 117.

70. Richtenberg to Rothschild Frères, 8 February 1839.

71. Apponyi (Austrian Ambassador to France) to Metternich, 12 February, 1839. Quoted in Gille $1965,297$.

72. See, for example, Logue 1973; Ibbotson 1975; and Miller and Reilly 1987. This market discount is computed by comparing the price at which the wartime issue is sold to the price at which similar bonds by the same governments traded in other circumstances. 


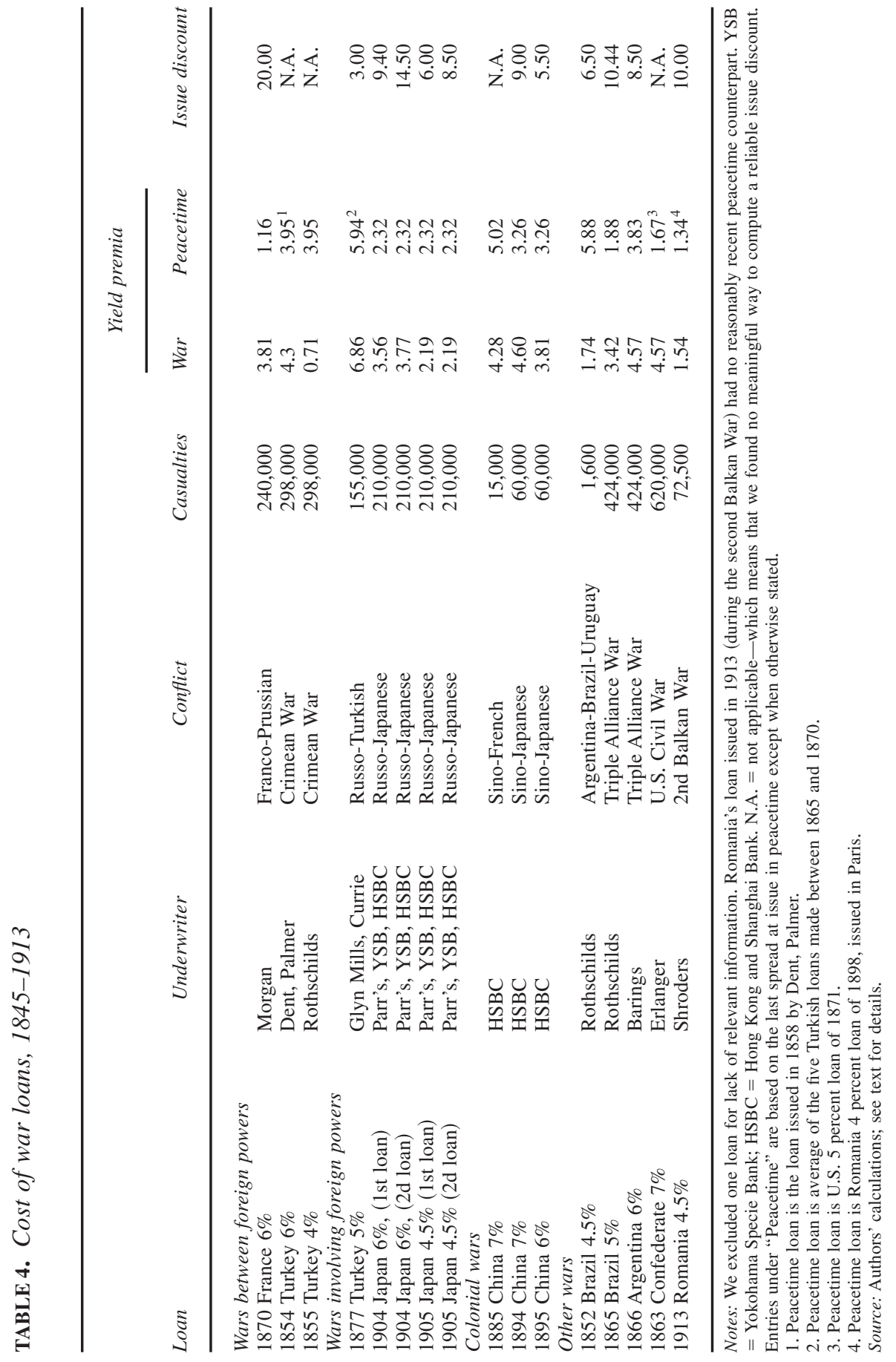


A first striking result is that with only a single exception, prestigious banks never funded wars involving any power. It is consistent with the view that all wars involving powers were dangerous for prestigious banks' charters. The exception is the 1855 loan to fund the war effort by the Ottoman Empire in the Crimean War. Polanyi brushed the episode aside as "a more or less colonial event" Crimean loan was guaranteed by Britain and France permitting a different interpretation: an Ottoman default was not a reputational risk for the Rothschilds because it would have led to the French and English governments footing the bill.

The other cases of prestigious banks' involvement are found in the "other wars" group: the Rothschilds' funding of Brazil (in 1852 and 1865) and Barings' funding of Argentina (in 1866). Why prestigious bankers became involved in these conflicts is again understood in terms of liability risk: there was little doubt about either war's outcome (the countries supported by the prestigious bankers would win) and the conflicts raised no geopolitical issue. The Argentina-Brazil-Uruguay War of 1852 was a miniconflict. During the Triple Alliance War against Paraguay (1865-66), Brazil and Argentina (helped by Uruguay) entered Paraguay and slaughtered its population. ${ }^{74}$ In other words, Haute Finance was not the Red Cross. Nor did prestigious banks dislike wars-they disliked only losers, or more precisely the risk of being found in losers' company. Consistently, prestigious banks could make an exception and promote a murderous war provided it would be a "winning" one and posed no geopolitical threat. Otherwise the war was discriminated against. Confirming this, Table 4 shows that all other conflicts were funded by ordinary houses.

Another feature worth mentioning is that war-time loans were penalized through higher spreads and also big-issue discounts. In several cases, this reflected the fact that countries at war were forced to go to a lesser underwriter. When prestigious banks got involved, wartime borrowing terms could actually be better than peacetime terms. For instance, the Crimean War loan to the Ottoman Empire by the Rothschilds had a lower spread than the peacetime benchmark: markets preferred to lend to the Turks-at-war certified by the House of Rothschild, than to the Turks-at-peace, underwritten by the House of Nobody. This is also true of the 1852 Brazilian loan which was made on better terms than the peacetime benchmark. This shows that bankers' reputation could outweigh the effect of war in determining spreads, and reinforces our notion of the control they had over war and peace.

France in 1870 (at war with Prussia) provides an example of the costs of a downgrade. Whereas the Rothschilds had brought out French international loans in previous decades, they now turned down this application. France's new government, adamantly wanting to fight the war, found itself going to Morgans, then a second-

73. Polanyi 1944, 5.

74. It was reported that about 70 percent of Paraguay's population was killed. See Abente 1987; and Whigham and Potthast 1999. 
order London shop. Compared to the peacetime benchmark, the yield spread for this loan was huge (260 basis points) and so was the issue discount, the highest of all in the group ( 20 percent). French officials painfully resented it, joking about "morganatic" financial terms. The joke rested on the consonance between the name of "Morgans" and "morganatic marriages" (marriages between one of royal birth and one of lower rank): the match "below France's kind" ran the risk of reflecting poorly on France's credit. ${ }^{75}$ Obviously, the penalty did not prove sufficient to prevent the war (and cautions against naïve views of "markets' dictatorship"), but the fact that there are not many other wartime issues in the table shows that in many cases, prestige did orient policies toward peace.

Table 4 finally shows that wartime market access through ordinary banks (all types of wars) was generally more costly than peacetime access with the same or other ordinary banks, but not systematically so. ${ }^{76}$ This is understandable because countries not sponsored by a serious bank in peacetime were considered risky and thus the advent of conflict was not always big news. A lot depended on war and country specifics, market expectations regarding the likely duration of war, as well as countries' own "reputation" (à la Tomz). Pushing the argument further, we predict that for a country lacking a reputation, a war might even have turned out to be a good thing. A country that won a war could, for example, "selfcertify" by exhibiting its military (and thus industrial) prowess. Of course, this was a gamble.

An example is the evolution of the spreads paid by Japan during its war against Russia (1904-05). When Japan attacked Russia by surprise, markets were anxious. Neither peacetime nor wartime Japan had been underwritten by a top-notch house. Accordingly, the first two loans had large spreads (130 and 150 basis points) and large-issue discounts (about 10 percent and 15 percent). The penalty however was less than France's, which is natural because Japan was not losing the support of prestigious banks. To facilitate market access, Japan tried, but failed (unsurprisingly), to secure the help of a prestigious house (Barings). ${ }^{77}$ But Japan soon wiped out Russia's Baltic fleet in Tsushima - the world got to know there was a new power in the Far East. Japan then returned to the markets and made two further loans, at lower spreads than peacetime benchmarks. ${ }^{78}$ It is a perfect illustration of our argument about the competition between private authorities and national governments in certification. Japan managed to establish its credit despite Haute Finance's lack of support.

75. Archives du Ministère des Finances, Fontainebleau, Negotiations for the Indemnity Loan, 1871.

76. For instance, the funding of China's "colonial wars" occurred uniformly at rates similar to those in peacetime.

77. Suzuki quotes Japanese authorities deploring that "Baring brothers had felt that they could not have their name ... publicly connected with Japan" although this "would have been of value to the Japanese government." Suzuki 1994, 92.

78. Rumors then started spreading that Barings and Rothschilds would be involved with Japan's future loans. Suzuki 1994. 


\section{Conclusion}

This study provides a new, industrial economics-based interpretation for Polanyi's idea that certain leading financial actors can control lending and successfully implement pro-peace policies. This interpretation rests on prestige, an asset that can help address asymmetries of information, and which is proprietary. We argue that Haute Finance's allergy to wars reflected its concern with protecting its own property rights over global financial certification. This runs counter to Polanyi's suggestion that Haute Finance found legitimacy by providing a public good (international peace). Had Polanyi been right, the Rothschilds would never have funded any war-but they did. The Rothschilds' logic should not be mixed up with broad humanitarian goals.

The "weapon" controlled by prestigious houses was the cost of the loans. Their refusal to underwrite a given loan could make it substantially more costly. When prestigious banks declined lending, ordinary banking houses could try and get involved: we found that about 20 percent of wars received London funding during the period 1845-1913, mostly from nonprestigious houses (European wars were never sponsored by prestigious banks). But going to the market through a lesser house was akin to a downgrade and in some cases, prestigious banks' walking away was enough to ensure that the loan would fail. Other things being equal, prestigious banks' refusal to fund European wars increased the costs of wars. This deterrent could tilt the balance in favor of peace. Our analysis and data suggest war borrowing was not "impossible" but rather, that it was severely penalized. Likewise, not all financiers were appeasing-only those with a name/brand to protect.

These findings provide a foundation for different attitudes toward war finance within the politically amorphous group of "financiers." The split operated according to an industrial organization divide. We explained why, during the Pax Britannica, prestigious banks were involved in diplomacy when ordinary ones were not. Having less or no reputation, ordinary houses had less to lose from underwriting a war loan. This shows how industrial organization can have an effect on international relations and IPE outcomes. We conclude that a better theory of the relation between banking and war should give more consideration to organization within the financial industry.

The theoretical contribution of this study is perhaps best understood in light of recent work. While our findings need not be exclusive of Kirshner's, they nonetheless represent a significant departure. In our model, Kirshner's financiers-atlarge and their weariness of war are replaced by a more precise market structure with attitudes and policies toward war-mongering explained by standing in the market. Likewise, we argued that Tomz's theory of self-certification through repeat play and investment in reputational capital should be extended and improved. We uncovered the existence of other players in the reputation game-players whose role Polanyi emphasized but failed to explain, and players whom Tomz simply ignored. Our analysis led us to recognize that governments' attempts at asserting 
their credibility can be supported or contradicted by the efforts of prestigious bankers who act as their competitors in the reputation game.

The competition between public and private certification authorities is a neglected but key dimension of international relations and should be the topic of future research. Theory could achieve significant mileage by looking at the interplay between reputation-providing intermediaries (rating agencies, the media, nongovernmental organizations, etc.) and states in the certification game, rather than focusing narrowly on reputation acquisition by "stand-alone" governments facing a continuum of investors. As a result, countries' own attempts at signaling their worth can be seen as competing against other certification providers. As the Japanese experience in the early twentieth century showed, a military victory provided this kind of self-certification. Japan signaled its worth itself by waging and winning a war against Russia. Therefore, preventing conflicts was essentially a way to fight new competitors. We can thus provide a rigorous interpretation of why prestigious bankers hated conflicts-they were, like the incumbent firm in the industrial economist's model, leery of competitors entering their market. War and peace were for them the continuation of business by other means.

To conclude, students of IPE should give up the earlier model of perfect competition and reputation acquisition through good behavior and start instead from the imperfect competition world we portray in this article. While the Rothschilds are ancient history, the theoretical issue they help identify and that Polanyi was the first to point his finger at (the importance of competition between private and public reputation signals and their ownership) is alive and well. Look at the world today.

\section{References}

Abente, Diego. 1987. The War of the Triple Alliance: Three Explanatory Models. Latin American Research Review 22 (2):47-69.

Aggarwal, Vinod K. 1989. Interpreting the History of Mexico's External Debt Crises. In The International Debt Crisis in Historical Perspective, edited by Barry Eichengreen and Peter H. Lindert, 140-88. Cambridge, Mass.: MIT Press.

. 1996. Debt Games: Strategic Interaction in International Debt Rescheduling. Cambridge: Cambridge University Press.

Barro, Robert J. 1987. Government Spending, Interest Rates, Prices, and Budget Deficits in the United Kingdom, 1701-1918. Journal of Monetary Economics 20 (2):221-47.

Beale, Marjorie A. 1999. The Modernist Enterprise: French Elites and the Threat of Modernity, 19001940. Palo Alto, Calif.: Stanford University Press.

Beatty, Randolph P., and Jay R. Ritter. 1986. Investment Banking, Reputation, and the Underpricing of Initial Public Offerings. Journal of Financial Economics 15 (1-2):213-32.

Berger, Suzanne. 2003. The First Globalization: Lessons from the French. Unpublished manuscript, Massachusetts Institute of Technology, Cambridge, Mass.

Bouvier, Jean. 1992. Les Rothschild. Brussels: Editions Complexe.

Brandeis, Louis D. 1913. Other People's Money and How the Bankers Use It. New York: Harper and Row. 
Bulow, Jeremy, and Kenneth Rogoff. 1989. A Constant Recontracting Model of Sovereign Debt. Journal of Political Economy 97 (1):155-78.

Carter, Richard B., and Steven Manaster. 1990. Initial Public Offerings and Underwriter Reputation. Journal of Finance 45 (4):1045-67.

Carter, Richard B., Frederick H. Dark, and Ajai K. Singh. 1998. Underwriter Reputation, Initial Returns, and the Long-Run Performance of IPO Stocks. Journal of Finance 53 (1):285-311.

Cashore, Benjamin. 2002. Legitimacy and the Privatization of Environmental Governance: How NonState Market-Driven (NSMD) Governance Systems Gain Rule-Making Authority. Governance: An International Journal of Policy, Administration, and Institutions 15 (4):503-29.

Chapman, Stanley. 1984. The Rise of Merchant Banking. London: Allen and Unwin.

Chemmanur, Thomas J., and Paolo Fulghieri. 1994. Investment Bank Reputation, Information Production, and Financial Intermediation. Journal of Finance 49 (1):57-79.

Chwieroth, Jeffrey M. 2007a. Testing and Measuring the Role of Ideas: The Case of Neoliberalism in the International Monetary Fund. International Studies Quarterly 51 (1):5-30.

. 2007b. Neoliberal Economists and Capital Account Liberalization in Emerging Markets. International Organization 61 (2):443-63.

Clarke, Hyde. 1878. On the Debts of Sovereign and Quasi-Sovereign States, Owing by Foreign Countries. Journal of the Statistical Society of London 41 (2):299-347.

Corti, Egon Caesar. 1928. The Rise of the House of Rothschild. New York: Cosmopolitan Book Corp. Dawson, Frank G. 1990. The First Latin American Debt Crisis. The City of London and the 1822-25 Loan Bubble. New Haven, Conn.: Yale University Press.

Depouhon, François. 1840. Considérations sur l'Emprunt Belge à Émettre. Brussels: Berthot.

Eaton, Jonathan, Mark Gersovitz, and Joseph E. Stiglitz. 1986. The Pure Theory of Country Risk. European Economic Review 30 (3):481-513.

Feis, Herbert. 1930. Europe, the World's Banker, 1870-1914: An Account of European Foreign Investment and the Connection of World Finance with Diplomacy Before the War. New Haven, Conn.: Yale University Press.

Fenn, Charles. 1883. Fenn's Compendium of the English and Foreign Funds, Debts and Revenues of all Nations. London: E. Wilson.

Flandreau, Marc. 2003. The Bank, the States, and the Market: An Austro-Hungarian Tale for Euroland, 1867-1914. In Monetary Unions: Theory, History, Public Choice, edited by Forrest H. Capie and Geoffrey E. Wood, 111-41. London: Routledge.

Flandreau, Marc, and Juan H. Flores. 2009. Bonds and Brands: Intermediaries and Reputation in Sovereign Debt Markets, 1820-1830. Journal of Economic History 69 (3):646-84.

- Forthcoming. Bondholders vs. Bond-Sellers? Investment Banks and Conditional Lending in the London Market for Foreign Government Debt, 1815-1913. European Review of Economic History.

Flandreau, Marc, Juan H. Flores, Norbert Gaillard, and Sebastián Nieto-Parra. 2010. The End of Gatekeeping: Underwriters and the Quality of Sovereign Bond Markets, 1815-2007. NBER International Seminar on Macroeconomics 6 (1):53-92.

Gille, Bertrand. 1965. Histoire de la Maison Rothschild. Vol. 1, Des Origines à 1848. Geneva: Droz. - 1967. Histoire de la Maison Rothschild. Vol. 2, 1848-1870. Geneva: Droz.

Gleditsch, Kristian Skrede. 2004. A Revised List of Wars Between and Within Independent States, 1816-2002. International Interactions 30 (3):231-62.

Harmes, Adam. 1998. Institutional Investors and the Reproduction of Neoliberalism. Review of International Political Economy 5 (1):92-121.

- 2001. Institutional Investors and Polanyi's Double Movement: A Model of Contemporary Currency Crises. Review of International Political Economy 8 (3):389-437.

Helleiner, Eric. 1994. States and the Reemergence of Global Finance: From Bretton Woods to the 1990s. Ithaca, N.Y.: Cornell University Press.

Hidy, Ralph W. 1949. The House of Baring in American Trade and Finance: English Merchant Bankers at Work, 1763-1861. Cambridge, Mass: Harvard University Press.

Hilferding, Rudolf. 1910. Das Finanzkapital. Eine Studie über die Jüngste Entwicklung des Kapitalismus. Vienna: Wiener Volksbuchhandlung. 
Hobson, John A. 1902. Imperialism: A Study. London: James Nisbet and Co.

Ibbotson, Roger G. 1975. Price Performance of Common Stock New Issues. Journal of Financial Economics 2 (3):235-72.

Jenks, Leland H. 1927. The Migration of British Capital to 1875. London: Thomas Nelson.

Kirshner, Jonathan. 2007. Appeasing Bankers: Financial Caution on the Road to War. Princeton, N.J.: Princeton University Press.

Klovland, Jan T. 2005. The Monetary Experiences of a Small Country Under the Silver and the Gold Standard: The Case of Norway 1820-1914. Unpublished manuscript, Norwegian School of Economics, Bergen, Norway.

Köver, Gyorgy. 1988. The London Stock Exchange and the Credit of Austria Hungary 1867-1871. Acta Historica Academiae Scientiarum Hungaricae 34 (2/3):159-70.

Lenin, Vladimir I. 1916. Imperialism, the Highest Stage of Capitalism. London: Lawrence.

Logue, Dennis E. 1973. On the Pricing of Unseasoned Equity Issues: 1965-1969. Journal of Financial and Quantitative Analysis 8 (1):91-103.

Lotz, Walther. 1890. Die Technik des Deutschen Emissionsgeschäfts: Anleihen, Konversionen und Gründungen. Leipzig, Germany: Duncker and Humblot.

Lysis. 1908. Contre L'oligarchie Financière en France. Paris: La Revue.

Megginson, William L., and Kathleen A. Weiss. 1991. Venture Capitalist Certification in Initial Public Offerings. Journal of Finance 46 (3):879-903.

Miller, Robert E., and Frank K. Reilly. 1987. An Examination of Mispricing, Returns, and Uncertainty for Initial Public Offerings. Financial Management 16 (2):33-38.

Mosley, Layna. 2003. Global Capital and National Governments. Cambridge: Cambridge University Press.

North, Douglass C., and Barry R. Weingast. 1989. Constitutions and Commitment: The Evolution of Institutions Governing Public Choice in Seventeenth-Century England. Journal of Economic History 49 (4):803-32.

Olson, Mancur. 1965. The Logic of Collective Action: Public Goods and the Theory of Groups. Cambridge, Mass.: Harvard University Press.

Pauly, Louis W. 1997. Who Elected the Bankers? Surveillance and Control in the World Economy. Ithaca, N.Y.: Cornell University Press.

Polanyi, Karl. 1944. The Great Transformation. New York: Farrar and Rinehart.

Reiter, Dan, and Allan C. Stam. 2002. Democracies at War. Princeton, N.J.: Princeton University Press.

Roberts, Richard. 1992. Schroders: Merchants and Bankers. Basingstoke, England: Macmillan.

Schultz, Kenneth A., and Barry R. Weingast. 2003. The Democratic Advantage: Institutional Foundations of Financial Power in International Competition. International Organization 57 (1):3-42.

Sinclair, Timothy J. 1994. Passing Judgement: Credit Rating Processes as Regulatory Mechanisms of Governance in the Emerging World Order. Review of International Political Economy 1 (1):132-59.

—_ 2005. The New Masters of Capital: American Bond Rating Agencies and the Politics of Creditworthiness. Ithaca, N.Y.: Cornell University Press.

Slaughter, Mihill. 1873. Rules and Regulations Adopted by the Committee for General Purposes of the Stock Exchange. London: Couchman.

Spence, Michael A. 1973. Job Market Signaling. Quarterly Journal of Economics 87 (3):355-74.

Stern, Fritz. 1977. Gold and Iron: Bismarck, Bleichroeder, and the Making of the German Empire. New York: Knopf.

Strange, Susan. 1996. The Retreat of the State: The Diffusion of Power in the World Economy. Cambridge: Cambridge University Press.

Suzuki, Toshio. 1994. Japanese Government Loan Issues on the London Capital Market 1870-1913. London: Athlone Press.

Tilly, Charles. 1992. Coercion, Capital, and European States, AD 990-1992. Cambridge, Mass.: Blackwell.

Tomz, Michael. 2007. Reputation and International Cooperation: Sovereign Debt Across Three Centuries. Princeton, N.J.: Princeton University Press. 
Whigham, Thomas L., and Barbara Potthast. 1999. The Paraguayan Rosetta Stone: New Insights into the Demographics of the Paraguayan War, 1864-1870. Latin American Research Review 34 (1):174-86.

Wolff, Jacques. 1992. Le Financier Ouvrard: L'Argent et la Politique. Paris: Tallandier.

Wright, Mark L.J. 2002. Reputations and Sovereign Debt. Unpublished manuscript, Stanford University, Palo Alto, Calif. Available at 〈http://elsa.berkeley.edu/users/obstfeld/e281_sp03/wright.pdf〉. Accessed 28 October 2011.

- 2005. Coordinating Creditors. American Economic Review 95 (2):388-92.

Ziegler, Philip. 1988. The Sixth Great Power: Barings 1762-1929. London: Collins. 